\title{
界面活性剤存在下のビニルモノマーの無触媒重合における 無機塩類の添加効果
}

\author{
（受付1973年 7 月 19日・審查終了1973年10月25日）
}

有田喜一*1 $\cdot$ 白石振作 $* 1 \cdot$ 妹尾 学*1 $\cdot$ 浅原照三*1

\begin{abstract}
要 旨メタクリル酸メチルおよびスチレンは, アニオン界面活性剤存在下の水媒体不均一重合 系で, 通常のラジカル重合開始剤を用いることなく顕著に重合した。重合開始反応とミセルの特性 との相関関倸を検討するため，反応系に無機塩類を添加したところ，画ニチオン酸ナトリウムを添 加することにより重合は影著に加速された。重合加速効果は, 业ニチオン酸ナトリウムの添加量が $4.2 \times 10^{-2} \mathrm{~mol} / l$ 以下の場合に認められ，それ以上では重合が阻止された。亜ニチオン酸ナトリウム の添加効果は，モノマーと界面活性剤との組合せにより，浔められるものと認められないものがあ った。

本反応系の重合開始には，ミセル界面に可溶化されたモノマーと亜ニチオン酸ナトリウムとが重 要な役割を演してていると推定した。
\end{abstract}

\section{1. 緒言}

著者らは数年来界面活性剤存在下のビニルモノマーの 重合について検討を加えており，スチレン $(\mathrm{St})$ あるいは メタクリル酸メチル (MMA) がアニオン界面活性剤, た とえばテトラプロピレンベンゼンスルホン酸ナトリウム (ABS) の存在下水媒体不均一重合系で, 通常のいわゆる ラジカル重合開始剤を用いることなく顕著に重合し，非 常に高分子量のポリスチレン (PSt) あるいはポリメタク リル酸メチル (PMMA) の安定なエマルジョンを高收率 で生成することを見いだし，本反応の開始にはミセル界 面の形成が不可欠の因子であると報告した ${ }^{1), 2) 。 ~}$

また，上記反応系にヒドロキノンやジフェニルピクリ ルヒドラジル (DPPH) のようなラジカル重合禁止剤を 添加することにより重合が禁止され，かつ MMA と St の共重合曲線より求めたモノマー反応性比がラジカル共 重合のそれと一致することより重合はラジカル機構で進 行すると報告した ${ }^{3)}$ 。

本反忍系に各種無機塩類を添加し，その添加効果を検 討したところ, 亜ニチオン酸ナトリウムを添加すると St および MMA ともに重合速度が非常に加速され，かつ その添加効果はモノマーと界面活性剤のある限られた組 合せにのみ顕著に現われることを見いだしたので，他の 無機塩類の添加効果と合わせて報告する。

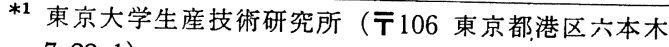
7-22-1)
}

\section{2. 実験}

\section{1 試薬}

MMA, St および各種脂肪酸ナトリウムは既報 ${ }^{1), 2) に ~}$ 従い精製して使用した。各種然機塩類のうち亜ニチオン 酸ナトリウムは和光純薬(侏)の市販品をそのまま使用し, 他はすべて試薬特級品を使用した。

\section{2 重合反応}

冷却管, ワクチン栓, 窒素遒入管, 擋拌子ならびに滴 下ロートを備えた $200 \mathrm{ml}$ の四ツロ平底フラスコに所定 量のイオン交換水，界面活性剤拉よび所定の無機塩を入 れ，あらかじめ反応温度で40尔間空素置換を行なったの ち，モノマーを滴下ロートより添加して重合を行なっ た。重合開始後, 所定時間ごとに約 $2 \mathrm{~g}$ の反応液を注射 器でサンプリングし精科したのち， $10 \mathrm{ml}$ のメタノール を添加して生成ポリマーを析出，口別し，60 $\mathrm{C}$ で 1 時間 真空乾燥を行ない, 生成ポリマー量を精科し, これから 重合速度を求めた。

\section{3 重合体の分析}

分子量の测定は既報に従い粘度法により求めた ${ }^{1), 2) 。 ~}$ 重合体末端基の定量は Ghosh らの方法に準じて行な っだ)。

\section{3. 結果亡考察}

界面活性剂存在下における MMA あるいは St の水媒 体無触媒重合の開始機構は, 現在の上ころまだ十分には 解明されていないが，いままでの検討結果から開始反応 にはミセル界面の存在が不可欠の因子であり，反応はラ 


\section{界面活性郕存在下のビニルモノマーの無触媒重合における無機塩類の添加奻果}

ジカル機構で進行し, ミセル界面で開始ラジカルが生成 すると考えられる1) -

ところで，コロイド分散系に電解質を添加すると反対 電荷イオンの界面への吸着によるスターン電位の低下, および水相中に㧍けるイオン強度の上昇による電気二重 層の圧縮が起こる5。。これらのことと重合反応との関連 を検討することにより重合開始機構について知見をうる ために, 反応系に各種無機塩類を添加し重合反応に与え る効果を検討した。その結果, 亜ニチオン酸ナトリウム を添加すると重合速度がきわめて大きくなり，重合率も 增大するという特異な現象が認められたので，その点に 関して詳細な検討を行なった。以下にそれらの結果を報 告する。

Table 1 に各種無機塩類の添加効果を St一オレイン酸 ナトリウム一水系を例に挙げて示した。既報においては 反応は主として $80^{\circ} \mathrm{C} て ゙$ 行なったが，亜二チオン酸ナトリ ウムを添加した場合, 重合温度 $80^{\circ} \mathrm{C} て ゙ は$ 重合速度が極端 に大きくなり，その測定が困難なため, $40^{\circ} \mathrm{C}$ を標準とした。

Table 1 から明らかなように, 亜ニチオン酸ナトリウ ムの存在しない場合，St はほとんど重合しなかった。し かしながら亜ニチオン酸ナトリウムを $6.4 \times 10^{-4} \mathrm{~mol}$ 添 加すると重合速度は著しく増大する。一方, 亜ニチオン 酸ナトリウム以外の無機塩については無添加の場合に比 してほとんど効果がなく, わずかに硫酸ナトリウムの添 加効果が認められるようであるが, 後述するようにその 添加効果は顕著でない。多価金属イオンの場合は, その 添加によりミセル電荷は顕著に中和され, かつ電気二重 層は圧縮されるので，ミセルは凝集しやすくなり，その 結果, ミセル界面の状態が大きく変化し, ついには破壊

Table 1. The effects of inorganic salts.

\begin{tabular}{l|c|c|c}
\hline \hline $\begin{array}{c}\text { Inorganic } \\
\text { salts }\end{array}$ & $\begin{array}{c}\text { Initial rate } \\
\text { of polymeri- } \\
\text { zation } \times 10^{3} \\
(\text { mol } / l \cdot \text { min })\end{array}$ & $\begin{array}{c}\text { Polymer } \\
\text { yield after } \\
2 \mathrm{hr} \\
(\%)\end{array}$ & $\begin{array}{c}\text { M.W. } \\
\times 10^{-6}\end{array}$ \\
\hline None & 0.09 & 4.7 & 5.1 \\
$\mathrm{Na}_{2} \mathrm{~S}_{2} \mathrm{O}_{4}$ & 3.46 & 35.3 & 12.2 \\
$\mathrm{NaHSO}_{3}$ & 0.09 & 1.9 & - \\
$\mathrm{Na}_{2} \mathrm{SO}_{4}$ & 0.69 & 4.9 & 10.0 \\
$\mathrm{Na}_{2} \mathrm{~S}_{2} \mathrm{O}_{3}$ & 0 & 2.8 & - \\
$\mathrm{Na}_{2} \mathrm{~S}_{2} \mathrm{O}_{5}$ & 0 & 1.0 & - \\
$\mathrm{ZnCl}_{2}$ & 0 & 0.0 & - \\
$\mathrm{CuCl}_{2}$ & 0 & 0.5 & - \\
$\mathrm{FeCl}_{3}$ & 0 & 1.6 & - \\
$\mathrm{AlCl}_{3}$ & 0 & 0.4 & - \\
$\mathrm{K}_{2} \mathrm{Cr}_{2} \mathrm{O}_{7}$ & 0.09 & 2.1 & - \\
\hline
\end{tabular}

Composition of the reaction mixture and reaction condition: inorganic salt $6 \times 10^{-4} \mathrm{~mol}$, Sodium oleate $1 \mathrm{~g}$, St $10 \mathrm{~g}$, water $100 \mathrm{~g}, 40^{\circ} \mathrm{C}$, under $\mathrm{N}_{2}$
Table 2. The effects of sodium dithionite $\left(\mathrm{Na}_{2} \mathrm{~S}_{2}\right.$ $\left.\mathrm{O}_{4}\right)$ and surfactants.

\begin{tabular}{|c|c|c|c|c|}
\hline $\begin{array}{l}\text { Mono- } \\
\text { mers }\end{array}$ & $\begin{array}{c}\mathrm{Na}_{2} \mathrm{~S}_{2} \mathrm{O}_{4} \\
(\mathrm{~g})\end{array}$ & Surfactants (g) & $\begin{array}{l}\text { Con- } \\
\text { version } \\
(\%)\end{array}$ & $\begin{array}{l}\text { M.W. } \\
\times 10^{-6}\end{array}$ \\
\hline MMA & 1.0 & ABS & 31.1 & 10.0 \\
\hline MMA & 0.1 & None & 0.7 & - \\
\hline MMA & None & ABS & 4.4 & - \\
\hline $\mathrm{MMA}^{\mathrm{a}}$ & 0.1 & ABS & 0 & - \\
\hline St & 0.1 & Sodium oleate 1.0 & 35.3 & 12.2 \\
\hline St & None & Sodium oleate 1.0 & 4.7 & 5.1 \\
\hline St & 0.1 & None & 0.2 & - \\
\hline St & 0.1 & ABS $\quad 1.0$ & 3.0 & 3.5 \\
\hline$\left.S t^{a}\right)$ & 0.1 & Sodium oleate 1.0 & 0 & - \\
\hline
\end{tabular}

a) Containing $0.1 \%$ of DPPH

Composition of the reaction mixture and reaction condition: Monomer $10 \mathrm{~g}$, water $100 \mathrm{~g}, 40^{\circ} \mathrm{C}, 2 \mathrm{hr}$, under $\mathrm{N}_{2}$

されるので重合は起こらなくなる。このことは既報で述 べたように有機溶媒を水の代わりに使用するとミセル界 面が形成されず，重合が開始されないという結果とも一 致している。

Table 2 に亜ニチオン酸ナトリウムの添加効果を詳細 に検討するために種々の反応系を設定して重合を行なっ た結果を示す。ラジカル重合禁止剤として DPPH を添 加した場合, St, MMA ともに重合は禁止される。

Ghosh らは反応温度 $30 \sim 70^{\circ} \mathrm{C}$, 反応時間 $24 \sim 48$ 時間の 重合条件で，MMA が覀ニチオン酸ナトリウム存在下の 水媒体で通常のラジカル重合開始剤を用いることなく重 合し，10 25\%の重合率で高分子量の PMMA を生成す ることを報告し，その開始機構として亜ニチオン酸ナト リウムから解離した $\mathrm{S}_{2} \mathrm{O}_{4}^{2-}$ よりアニオンラジカルが生 ビるとしている4)。この開始機構の妥当性を検討するた め， MMA あるいは St の重合を㝷ニチオン酸ナトリウ 厶存在下の水媒体中, 界面活性剤を用いず行なったが, Table 2 に示すように，われわれの重合条件 $\left(40^{\circ} \mathrm{C} ， 2\right.$ 時間）においては，重合体はほとんど得られず，Ghosh らの重合開始機構は一応無視できると考えられる。ま た，染色法4)により 重合体末端の $\mathrm{SO}_{3}$ 基の定量を行な ったところ, 得られた重合体から $\mathrm{SO}_{3}$ を検出すること はできなかった。

既報2),日) に述べたように，われわれの系においてはモ ノマーあるいは界面活性剤中に, 開始種としては考えに くい程度であるが, 極微量の過酸化扬が存在する。これ らの過酸化物が還元剂としての亜ニチオン酸ナトリウム とRedox 系を組み, 重合を開始する可能性も考えられ るが，このことも同様に還元剤としての作用を有する亜 硫酸水素ナトリウムの添加効果がほとんど認められない 
Table 3. The effects of surfactants.

\begin{tabular}{c|lr|r|r|r}
\hline \hline $\begin{array}{c}\text { Mono- } \\
\text { mers }\end{array}$ & \multicolumn{1}{|c|}{ Surfactants } & $\begin{array}{c}\text { Poly- } \\
\text { meriza- } \\
\text { tion } \\
\text { temp. } \\
\left({ }^{\circ} \mathrm{G}\right)\end{array}$ & $\begin{array}{c}\text { Con- } \\
\text { version } \\
(\mathrm{wt} \%)\end{array}$ & $\begin{array}{c}\mathrm{M} . \mathrm{W} . \\
\times 10^{-6}\end{array}$ \\
\hline MMA & ABS & 1.0 & 40 & 31.1 & 10.0 \\
MMA & Sodium oleate & 1.0 & 40 & 2.7 & - \\
St & ABS & 1.0 & 40 & 3.0 & 3.5 \\
St & Sodium oleate & 1.0 & 40 & 35.3 & 12.2 \\
St & Sodium elaidate & 1.0 & 40 & 28.2 & 15.0 \\
St & Sodium undecilate 3.0 & 40 & 10.6 & 11.6 \\
St & Sodium stearate & 1.0 & 40 & 1.5 & - \\
St & Sodium stearate & 1.0 & 70 & $\left.17.8^{\mathrm{a}}\right)$ & 4.5 \\
$\mathrm{St}$ & Sodium stearate & 1.0 & 70 & 82.9 & 9.2 \\
\hline
\end{tabular}

a) without $\mathrm{Na}_{2} \mathrm{~S}_{2} \mathrm{O}_{4}$

Composition of the reaction mixture and reaction condition: Monomer $10 \mathrm{~g}, \mathrm{Na}_{2} \mathrm{~S}_{2} \mathrm{O}_{4} 0.1 \mathrm{~g}$, water $100 \mathrm{~g}, 2 \mathrm{hr}$, under $\mathrm{N}_{2}$

ことから一応無視できる。また，亜ニチオン酸ナトトリウ ムの酸化分解生成物による効果でないことも, Table 1 に示したように，チ才硫酸ナトリウムあるいはピロ硫酸 ナトリウムを添加した場合，ほとんど重合活性を示して いないことから明らかである。

一方, 水相でラジカルが発生するのであれば，界面活 性剤の種類による効果は小さいと考えられ，とくに $\mathrm{AB}$ $\mathrm{S}$ などアニオン界面活性剤は一般にモノマーに対する選 択性が小さく，多くのモノマーの乳化重合反応を安定に 進行させることが知られているので ニチオン酸ナトリウム系あるいは $\mathrm{St一}$ 一水一咞二チオン 酸ナトリウム系における各種アニオン界面活性剤の効果 を検㨍し，その結果を Table 3 に示した。Table 3 から， MMA の場合には ABS が，St の場合には脂肪酸ナトリ ウムが有効であることが明らかとなった。脂肪酸ナトリ ウム塩のうち，ステアリン酸ナトリウムの効果が認めら れないのは, 反応温度 $40^{\circ} \mathrm{C}$ 条件下では, ステアリン酸 ナトリウムの溶解度が非常に小さく，ミセルが形成され ないことが原因と考えられる。そこで，反応温度を $70^{\circ} \mathrm{C}$ にしたところ，ステアリン酸ナトリウムの場合にも明り ような加速効果が認められた。

以上のように，本反応系では界面活性剈の種類を変え ることにより重合率が大きく変化していることから，開 始機構は単に Ghosh らの述べているような過程，ある いはモノマーや界面活性剂に含まれている過酸化物と亜 ニチオン酸ナトリウムとの水相における Redox 系によ る過程とは考えられず，ミセル界面に可溶化されたモ， マーと要ニチオン酸ナトリウムとの相互作用を含む過程 が考えられる。

そこで亜ニチオン酸ナトリウムの添加効果をさらに詳

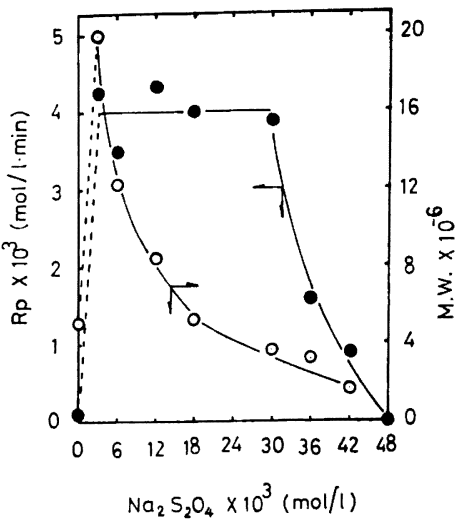

St $10 \mathrm{~g}$, sodium oleate $1 \mathrm{~g}$, water $100 \mathrm{~g}, 40^{\circ} \mathrm{C}$

Fig. 1. The effects of the amounts of sodium dithionite.

細に検討するため，St一オレイン酸ナトリウム一皮系を 例にとって, 亜ニチオン酸ナトリウムの添加量と重合速 度の関倸を求めた。結果を Fig. 1 に示す。亜ニチオン 酸ナトリウムの添加による重合速度の変化は, 添加量 3 $\times 10^{-3} \sim 3 \times 10^{-2} \mathrm{~mol} / l$ までは重合速度がほとんと一定 であり, かつ重合加速効果は非常に顕著であるが，添加 量が $3 \times 10^{-2} \mathrm{~mol} / l$ 以上になると重合速度は急激に減少 する。このような挙動は Ghosh らの奏験でも認められ ており，彼らの報告によれば，互ニチオン酸ナトリウム は $0.4 \times 10^{-3} \sim 1.5 \times 10^{-2} \mathrm{~mol} / l$ の範囲内で有効で, 2.0 $\times 10^{-2} \mathrm{~mol} / l$ をこえると反応系の $\mathrm{pH}$ が13にもなり，重 合が禁止されると報告している。われわれの系において は彼らの報告よりはるかに高い添加濃度まで有効に作用 しているのは $\mathrm{pH}$ の効果が緩和されているためであろ 5。

本系に㧊いて生成する重合体の分子量は，Fig. 1 加 明らかなように，亜ニチオン酸ナトリウムの添加量とと もに急激に減少する。このことは添加量が増加すると発 生するラジカル数が増加し，カップリング反応による停 止反応が大きくなるためと考えられる。添加量がさらに 増加すると分子量はほぼ一定となるが，その值は無添加 の場合に得られる重合体の分子量にほぼ等しい。

界面活性剂の対イオンと同種のイオンをもつ電解質を 添加した場合, 電解質濃度が増加するにつれて CMC が 低下し，ミセルの会合度は增加することが知られてい る8)。たとえば， ABS一水系に硫酸ナトリウムを加えて いくとミセル会合度は Table 4 に示したように変化す る8)。ミセル会合度が変化した場合，ミセル界面の状態 はスターン電位層を含め当然変化することが期待される ので，その重合活性に対する影響を検討し，その結果を Table 4 に示した。Table 4 より明らかなように, ミセ 
Table 4. The effects of sodium sulfate.

\begin{tabular}{c|c|c|c}
\hline \hline $\begin{array}{c}\mathrm{Na}_{2} \mathrm{SO}_{4} \\
(\mathrm{~g})\end{array}$ & $\begin{array}{c}\text { Aggregation } \\
\text { number of } \\
\text { micelles }\end{array}$ & $\begin{array}{c}\text { Initial } \\
\text { polymerization } \\
\text { rate } \times 10^{3} \\
(\mathrm{~mol} / l \cdot \mathrm{min})\end{array}$ & $\begin{array}{c}\mathrm{M} . \mathrm{W} . \\
\times 10^{-6}\end{array}$ \\
\hline None & $3 \sim 5$ & 0.44 & 7.74 \\
0.57 & 64 & 0.30 & 5.91 \\
0.84 & 59 & 0.32 & 7.91 \\
1.50 & 210 & 0.11 & 6.13 \\
1.72 & 370 & 0.06 & 6.46 \\
2.82 & - & 0.02 & 2.73 \\
\hline
\end{tabular}

Composition of the reaction mixture and reaction condition: MMA $10 \mathrm{~g}$, ABS $1 \mathrm{~g}$, water $100 \mathrm{~g}, 80^{\circ} \mathrm{C}$, under $\mathrm{N}_{2}$

Table 5. The activation energy of St-sodium oleate and MMA-ABS system.

\begin{tabular}{c|c|c|c|c|c|c}
\hline \hline $\begin{array}{c}\text { Mono- } \\
\text { mers }\end{array}$ & & \multicolumn{3}{|c|}{ Reaction temperature $\left({ }^{\circ} \mathrm{C}\right)$} & $\begin{array}{c}\text { Activation } \\
\text { cnergy } \\
\text { (kcal/mol) }\end{array}$ \\
\cline { 2 - 7 } & & 30 & 40 & 50 & 60 & 136 \\
\hline \multirow{2}{*}{ St } & Rp & 1.73 & 3.20 & 5.80 & 14.45 & 13 \\
& M.W. & 1.65 & 4.24 & 1.05 & 0.48 & \\
\hline \multirow{2}{*}{ MMA } & Rp & 2.44 & 4.24 & 7.95 & 10.57 & 9.9 \\
& M.W. & 1.29 & 1.00 & 0.83 & 0.58 & 9.9 \\
\hline
\end{tabular}

Rp's are presented in terms of $(\mathrm{mol} / l \cdot \mathrm{min}) \times 10^{-3}$ M.W.'s are presented by $\times 10^{7}$

Composition of the reaction mixture and reaction condition: Monomer $0.1 \mathrm{~mol}$, surfactant $1 \mathrm{~g}$, water $100 \mathrm{~g}$, under $\mathrm{N}_{2}$

ルの会合度が増加する上急激に重合速度が低下する。こ の効果は亜ニチオン酸ナトリウムの場合にも当然傎いて いるのであろう。しかしながら，会合度の増加が少な
い, 添加量 $0 \sim 1.0 \mathrm{~g} / 100 \mathrm{ml}$ の範囲では重合速度は無添 加の場合と大差なく，このことは硫酸ナトリウムの重合 加速効果がほとんどないことを示している。

本系における St ならびに MMAの重合活性化ェネル ギーを 30〜 60 ${ }^{\circ} \mathrm{C}$ で測定したところ，Table 5 に示したよ うに, St の場合 $13.6 \mathrm{kcal} / \mathrm{mol}, \mathrm{MMA}$ の場合 $9.9 \mathrm{kcal}$ /mol であった。この結果は無ニチオン酸ナトリウムを 添加しない場合に比べ多少大きい。

以上のように，亜ニチオン酸ナトリウムを添加した場 合，乙の重合加速効果は非常に特異的であり，その重合 開始機辈にはミセル界面に可溶化されたモノマーと亜ニ チオン酸ナトリウムとの相互作用が関与していると考え られる。

付記 終りに本研究に終始多大な努力をはらっていた たきました早川洋二，森川浩一郎両君に深く感謝いたし ます。

\section{文献}

1) T. Asahara, M. Senō, S. Shiraishi, Y. Arita: Bull. Chem. Soc. Jap., 45, 2862 (1972)

2) 有田喜一, 白石振作, 妹尾 学, 浅原照三：日 化, 1973, 1042

3) Y. Arita, S. Shiraishi, M. Senō, T. Asahara: Bull. Chem. Soc. Jap., 46, 2599 (1973)

4) P. Ghosh, S. Chander, S. Palit: Indian J. Chem., 3, 197 (1965)

5) 空井宗一：“高分子ラテックスの化学”高分子 刊行会, p. 187 (1970)

6) T. Asahara, M. Senō, S. Shiraishi, Y. Arita: Bull. Chem. Soc. Jap., 43, 3895 (1970)

7) 室井宗一：文献 (5), p. 36

8) A. M. Mankowich: Ind. Eng. Chem., 47, 2175 (1955) 